\title{
Implementation of e-commerce as a positive impact by technological innovation
}

\section{Tasrifan}

Universitas Indonesia, Depok - Indonesia, (tasrifan65@gmail.com)

\begin{abstract}
A number of technology usage is very high in the last four years around the world, specifically Indonesia. Based on e-marketer survey, since 2014, Indonesia is standing on number six, with number of 88 million people in Indonesia are using Electronic Commerce and continuously increase every year. The purpose of this paper is to know the effect of innovation on technology in purpose of using Electronic Commerce. Electronic Commerce means a transaction of sell and buy product and services through electronic system, such as smartphones, laptops, and netbooks. Internet is the most factor to have online transaction. Electronic Commerce is divided into four types, which are: Business to Business (B2B), Business to Consumer (B2C), Consumer to Consumer (C2C) and Consumer to Business (C2B). In conclude, online transaction make a business become easier and fast.
\end{abstract}

Keywords: technology, innovation, e-commerce.

\section{Introduction}

Technology and the internet in the world developed so rapidly. The Internet can be used as a place for education, tourism, and electronic commerce. The current explosive trade is online trading. Ease in accessing the internet can be used as a business support either individually or a corporate institution. System changes that occur in ranging from advertising, buying and selling, how to interact between humans.

This technology-based trading activity supports the creation of e-commerce systems, e-marketing, e-education, e-government and so on (Oetomo, 2001: 3). Electronic Commerce is a concept that can be described as a process of buying and selling goods or services on the World Wide Web Internet (Shim, Qureshi, Siegel, et al 2000).

The e-commerce according to Turban (2001) is identified consisting of Business to Business (B2B) and Business to Customer (B2C). B2B is an e-commerce application between businesses, while B2C is an e-commerce application between a business or a company with a consumer. B2C services themselves vary from e-malls or cybermall services, online advertising, electronic catalogs, online payment, customer service, online service industries. 
Businesses with e-commerce systems are an opportunity to reach a broad and even global market with one-to-one marketing strategy. This is of course offset by the enormous benefits that can be gained with the utilization of e-commerce for business people. And between the seller and the buyer they do not have to meet.

Online business sales provide a great opportunity to do business for every community, including students who have the opportunity to become a businessman in small scope. With this, provide capital to become a professional businessman in the future. In online transactions, every manufacturer has the opportunity to market all kinds of products in accordance with consumer interest. In other words, E-Commerce can improve the people's economy because the transaction does not see who the manufacturers are using it.

This research will explain about e-commerce is a positive impact of the application of innovation in technology. The empirical study uses the variables of internet application research for product marketing (e-commerce), perceptions of benefits and constraints.

\section{Method}

The sample to be studied is the e-commerce transaction as a technological innovation in the world of commerce. The high use of internet among the community in terms of transactions without the need face to face directly between the seller and the buyer. The basis of research used by the author is the quality based on previous studies in technological innovation that occurred.

\section{Result and Discussion}

\section{Innovation Theory}

New ideas in observing a phenomenon that occurs, produce a product in the form of goods and services with better quality and results and can be used by the public and make improvements and improvements to something that already exist, where this activity can be done by groups and individuals. (Stephen Robbins: 1994).

Innovating in business is necessary, to increase the profitability of sales of producer products. Innovation cannot be done easily, because it requires a positive response from the community in accepting any changes made by the manufacturer. The transition of conventional sales to online advertising is very big for producers. This is because the prospective consumer can easily choose directly every product offered.

\section{Internet Theory}

Internet began to be known in Indonesia in the 1990s, which at that time the Internet serves to provide information to the public via radio. At that time, the use of the Internet is managed together to produce clear information. With the development of the era, in general the internet is managed by individuals in the business scope.

The population growth in Indonesia each year is about four million people (Source: BKKBN). It states that the execution rate of e-commerce transactions is very high because internet usage comes from every circle of society, whether teenagers, adults or parents. Every individual has the opportunity to conduct online transactions in daily needs. In the last four years, precisely in 2014, there are 88 million Indonesians from the whole population.

Internet plays an important role in the implementation of online transactions. Where, the internet can connect the networks between computers in order to create communication between producers 
and consumers. The existence of the internet, making it easy for manufacturers to promote products (goods and services) to be consumed by consumers directly.

\section{E-Commerce Theory}

Advances in information technology has been able to create a global network called the Internet. Utilization of the internet has also been developed in various aspects of life. Various existing applications developed from 3 (three) basic application categories are: (1) Discovery is an application for information access (browsing and information retrieval or searching). (2) Communication is an email, chat, newsgroup. (3) Collaboration is an application for collaboration between individuals or classes, such as workflow systems, screen sharing, visual teleconferencing (teleconferencing), group decision support systems (GDSS).

Utilization of the Internet for various business activities called E-Commerce. Business activities conducted online that can include marketing, promotion, public relations, transactions, payments, and scheduling delivery of goods, and is still very open possibility of innovations in online business activities in line with the development of e-commerce technology itself.

The use of e-commerce for businesses that switch to online will be very likely to reach a wider consumer due to the lack of limits on internet access (Schneider, 2012). E-commerce gives freedom to the producers in choosing what products are sold in accordance with the needs of consumers.

\section{Conclusion}

In conclusion that, the innovations haveoccurred in technology is instrumental in improving the economy of society. The number of sales and purchases a very good increase because each individual can make transactions wherever and whenever. E-commerce can reduce the unemployment rate

\section{References}

Diaconu, Mihaela. (2011). Technological Innovation: Concept, Process, Typology and Implications in the Economy. Vol XVIII (2011), No. 10(563), pp. 127-144.Diakses tanggal 29 Januari 2018.

Juninton, Pesta Rafly. (2015). Pengaruh Teknologi Informasi Terhadap Perkembangan E-Commerce Dalam Dunia Bisnis.Diakses tanggal 29 Januari 2018.

Yulianto. Alfiah, Fifitdkk. (2015). Analisa Peranan Teknologi Internet Sebagai Media Transaksi E-Commerce Dalam Meningkatkan Perkembangan Ekonomi. Vol 3, No. 1. Diakses tanggal 30 Januari 2018.

Juanty, Dhara.Peranan dan Implementasi Big Data Pada E-Commerce Menggunakan EDI (Electronic Data Interchange).Diakses tanggal 30 Januari 2018.

Maulana, Miftah Shabur. Susilo, Herudkk. (2015). Implementasi E-Commerce Sebagai Media Penjualan Online (StudiK kasus Pada Toko Pastbrik Kota Malang).Diakses tanggal 30 Januari 2018. 